\title{
PENGARUH MARKET ORIENTATION, INOVASI PRODUK, DAN KUALITAS PRODUK TERHADAP KINERJA BISNIS DALAM MENCIPTAKAN KEUNGGULAN BERSAING
}

\author{
Tulus Haryono \\ Fakultas Ekonomi dan Bisnis UNS \\ Sabar Marniyati \\ FISIP Universitas Surakarta
}

\begin{abstract}
The research shown : (1) market orientation direct effect positive and significant to competitive adventage on CV Multi Global Agrindo. (2) market orientation indirect effect positive but not significant to competitive adventage on CV Multi Global Agrindo by business performance. (3) Product inovation direct effect positive and significant to competitive adventage on CV Multi Global Agrindo. (4) Product inovation indirect effect positive and significant to competitive adventage on CV Multi Global Agrindo by business performance. (5) product quality direct effect positive and significant to competitive adventage on CV Multi Global Agrindo. (6) product quality indirect effect positive and significant to competitive adventage on CV Multi Global Agrindo by business performance. (7) business performance is direct effect positive and significant to competitive adventage on CV Multi Global Agrindo.
\end{abstract}

Keyword : market orientation, product inovation, product quality, business performance, competitive advantage

\begin{abstract}
ABSTRAK
Hasil penelitian menunjukkan: (1) orientasi pasar berpengaruh langsung positif dan signifikan terhadap daya saing CV Global Agrindo. (2) Orientasi pasar secara tidak langsung berpengaruh positif namun tidak signifikan terhadap persaingan usaha CV Multi Global Agrindo berdasarkan kinerja usaha. (3) Inovasi produk langsung berpengaruh positif dan signifikan terhadap competitive adventage pada CV Multi Global Agrindo. (4) Inovasi produk secara tidak langsung berpengaruh positif dan signifikan terhadap persaingan usaha CV Multi Global Agrindo berdasarkan kinerja usaha. (5) kualitas produk langsung berpengaruh positif dan signifikan terhadap competitive adventage pada CV Multi Global Agrindo. (6) kualitas produk tidak langsung berpengaruh positif dan signifikan terhadap persaingan usaha CV Multi Global Agrindo berdasarkan kinerja usaha. (7) Kinerja bisnis berpengaruh langsung positif dan signifikan terhadap persaingan usaha CV Global Agrindo.
\end{abstract}

Kata kunci : orientasi pasar, inovasi produk, kualitas produk, kinerja usaha, keunggulan kompetitif 
Dalam dunia bisnis pemasaran mempunyai peranan yang sangat penting. Suatu perusahaan harus bisa menerapkan pemasaran yang baik untuk dapat bersaing dengan perusahaan yang lain. Definisi yang paling luas menerangkan secara jelas arti pemasaran yang dikemukakan oleh William J Stanton (1990) adalah suatu sistem keseluruhan dari kegiatan-kegiatan usaha yang ditujukan untuk merencanakan, menentukan harga, mempromosikan dan mendistribusikan barang dan jasa yang dapat memuaskan kebutuhan baik kepada pembeli yang ada maupun kepada pembeli potensial.

Pembeli dalam hal ini adalah perilaku konsumen dalam melakukan keputusan pembelian suatu barang dan jasa. Pengertian perilaku konsumen menurut James $F$ Engel (1994) adalah kegiatan individu-individu yang secara langsung terlibat dalam mendapatkan dan mempergunakan barang dan jasa, termasuk di dalamnya proses pengambilan keputusan dan kegiatan perusahaan yang semua ini melibatkan individu dengan menilai, mendapatkan dan mempergunakan barang dan jasa.

Selain itu juga diharapkan agar perusahaan dapat melakukan ekspansi atau perluasan pasar. Jika perusahaan telah memperhatikan perilaku konsumen, maka langkah selanjutnya adalah membuat kebijaksanaan strategi pemasaran yang berkaitan dengan produk. Sudah dapat dipastikan bahwa konsumen memilih produk yang berkualitas baik dibanding produk lain. Memang tidaklah mudah untuk memproduksi barang yang berkualitas baik pada saat bahan bakunya mahal atau bahkan membuatnya harus menggunakan teknologi yang canggih. Akan tetapi setidaknya produsen tetap memperhatikan kualitas produk yang pernah diluncurkan ke pasaran. Berhasil tidaknya suatu perusahaan sangat tergantung pada reaksi individu dan dari reaksi kelompok yang dinyatakan dalam bentuk pola pembelian. Oleh karena itu pengetahuan dan pemahaman perilaku konsumen menjadi sangat penting.

Untuk memenuhi kebutuhannya konsumen harus mempertimbangkan banyak hal sampai dengan melakukan keputusan pembelian. Proses pembelian menurut Philip Kotler (1995) melalui lima tahap yaitu : pengenalan kebutuhan, pencarian informasi, evaluasi alternatif, keputusan pembelian dan perilaku setelah pembelian.

Penelitian yang dilakukan oleh Eric M. Olson, Stanley F. Slater \& G. Tomas M. Hult (2005) tentang The Performance Implications Of Fit Among Business Strategy, Marketing Organization Structure, And Strategic Behavior hasil penelitiannya menguji suatu model yang sesuai, dan mendalilkan bahwa semua performansi perusahaan dipengaruhi oleh seberapa baik karakteristik struktural organisasi pemasaran (misal formalisasi, sentralisasi, dan spesialisasi) dan penekanan perilaku strategis (yakni kustomer, kompetitor, inovasi, dan pengontrolan biaya) melengkapi keunggulan bersaing alternatif (yakni prospektor, analiser, biaya rendah dan perbedaan elemen pemasaran).

Penelitian lain yang dilakukan oleh Tonny Garret (1996) dengan judul service product development for sustainable competitive advantage : the use of the sources position and performance model menjelaskan bahwa keunggulan bersaing dalam perusahaan jasa mempunyai hubungan yang erat dengan penggunaan sumber daya yang ada dalam perusahaan melalui peningkatan kinerja. Model dan pemanfaatan budaya yang ada dalam perusahaan merupakan kunci utama peningkatan inovasi perusahaan, sehingga mampu meningkatkan keunggulan bersaing perusahaan. Berdasarkan uraian tersebut menunjukkan bahwa upaya perusahaan jasa dalam meraih konsumen-konsumennya dilakukan dengan penciptaan orientasi pasar dan orientasi pelanggan-pelanggannya. Penggunaan inovasi dalam perusahaan jasa merupakan kunci persaingan yang utama.

Penelitian yang dilakukan oleh Bharadwaj et al. (1993) "Sustainable Competitive Advantage in Services Industries : A Conceptual Model and Research Propositions". Studi ini meneliti keunggulan bersaing berkelanjutan pada perusahaan jasa dan variabelkeunggulan bersaing berkelanjutan memiliki dimensi (a) Harus bernilai, (b) 
Harus jarang dimiliki oleh pesaing, (c) Harus dapat ditiru tapi tidak sempurna. Dan (d) Harus tidak ada secara strategi yang sama untuk mensubtitusi keahlian atas sumber daya ini.Dalam studi ini telah menemukan bahwa keunggulan bersaing sangat penting dalam mencapai kinerja superior pada perusahaan jasa, dimana keung gulan bersaing dapat diperoleh dengan memiliki seperangkat keahlian dan kompetensi yang unik sehingga sulit ditiru oleh para pesaing.

Penelitian ini mengambil studi obyek pada CV. Multi Global Agrindo (CV. MGA) yang bergerak dibidang perbenihan tanaman. Perusahaan ini berdiri dilatarbelakangi karena adanya peluang dan tantangan, bahwa Indonesia adalah negara agraris yang sangat membutuhkan sarana produksi berupa benih tanaman dalam jumlah yang besar dan benih adalah merupakan blue print agribisnis, dimana dengan menggunakan benih yang bermutu tinggi akan menjamin keberhasilan dari agribisnis. Sementara $90 \%$ kebutuhan benih hortikultura tanaman semusim yang berupa benih hidrid ( F1) adalah benih introduksi yang berasal dari import.

Dari segi besarnya volume kebutuhan dan nilai komoditas benih tersebut sangat menjanjikan sebagai peluang dan sekaligus kesempatan untuk di usahakan. Namun untuk melakukan kegiatan usaha tersebut memerlukan korbanan tenaga, biaya dan waktu yang cukup besar dengan proses teknologi yang cukup memadai. Oleh karena itu maka harus diperhitungkan betul-betul karena industri perbenihan harus dilakukan melalui proses riset yang lama, sementara di pasar sudah tersedia produk-produk dari perusahaan yang telah mapan, mempunyai brand image dan brand equity yang mantap. Perusahaan-perusahaan tersebut adalah : Known You Seed-Taiwan; Hung Nong-Korea; Chai Tai-Thailand; Takii, Sakata, Mikado-Jepang; As Growt-Amerika; Yates-Denmark, dsb.

Pertimbangan antara peluang dan kesempatan vs keterbatasan dan kelemahan dipadukan dengan motivasi bahwa sebaiknya sebagai bangsa yang mandiri harus berupaya dapat memproduksi atas barang-barang kebutuhan yang digunakan sendiri, maka CV. MGA ingin berperan sesuai hal tersebut diatas bergerak di salah satu sub sektor pertanian di bidang industri perbenihanBerikut kebutuhan benih yang selalu meningkat dari waktu kewaktu.

CV. MGA salah satu perusahaan agribisnis yang bergerak dihulu dengan menyiapkan sarana produksi pertanian berupa benih kepada para petani atau pembudidaya tanaman (on farm) dan setelah itu produk dari on farm akan didistribusi keagribisnis hilir yaitu distribusi pemasaran produk segar. Walaupun sasaran utama penjualan produk benih kepada para konsumen (petani dan atau pembudidaya tanaman) yang harus diperhatikan kepuasannya, tetapi CV. MGA harus ikut pula memperhatikan kebutuhan / kepuasan pedagang serta konsumen akhir akanproduk buah dan sayur.

Berdasarkan keadaanusaha dan perdagangan benih diatas dan semangat berkontribusi terhadap perkembangan dan kemajuan bisnis perbenihan nasional maka penulis melakukan penelitian tentang pengaruh Market Orientation, Inovasi Produk, dan Kualitas Produk terhadap Kinerja Bisnis dalam Menciptakan Keunggulan Bersaing pada CV. Multi Global Agrindo ( CV. MGA). Tujuan yang ingin dicapai dalam penelitian adalah :

1. Untuk menganalisamarket orientation berpengaruh secara langsung terhadap keunggulan bersaing CV Multi Global Agrindo.

2. Untuk menganalisamarket orientation berpengaruh terhadap keunggulan bersaing melalui kinerja bisnis pada CV Multi G lobal Agrindo.

3. Untuk menganalisainovasi produk berpengaruh secara langsung terhadap keunggulan bersaing pada CV Multi Global Agrindo.

4. Untuk menganalisainovasi produk berpengaruh terhadap keunggulan bersaing secara tidak langsung melalui kinerja bisnis pada CV Multi Global Agrindo.

5. Untuk menganalisakualitas produk berpengaruh terhadap keunggulan bersaing secara langsung pada CV Multi Global Agrindo. 
6. Untuk menganalisakualitas produk berpengaruh terhadap keunggulan bersaing secara tidak langsung melalui kinerja bisnis pada CV Multi Global Agrindo.

7. Untuk menganalisa kinerja bisnis berpengaruh terhadap keunggulan bersaing secara langsung pada CV Multi Global Agrindo.

\section{TELAAH PUSTAKA}

\section{Market Orientation}

Menurut Bharadwaj Varadarajan dan Jayachandran (1999) "Orientasi pasar adalah seperangkat tindakan nyata yang memungkinkan perusahaan mempertahankanvariasipermintaan dan penawaran pasar dan memberikan respon yang tepat terhadap berbagai perubahan yang terjadi". Market oriented strategic planning adalah proses manajerial dari pengembangan dan perawatan antara obyektivitas organisasi, skill, dan sumber daya serta perubahan peluang pasarnya. Tujuan strategi ini adalah untuk membentuk bisnis perusahaan dan produk sehingga mereka mampu mencapai target laba dan pertumbuhan.

Orientasi pasar dipandang dari perspektif perilaku memperlihatkan tiga tindakan penting, yaitu upaya menghasilkan intelijen pasar (dissemination of the intelligence) ke seluruh departemen, dan ketanggapan (responsiveness) seluruh organisasi untuk menindaklanjuti hasil intelijensi pasar (Kohli Ajay K dan Bernard J. Jaworski, 1993). Ketanggapan organisasi ini mencakup ketanggapan untuk mendesain. Misalnya, menggunakan intelijensi pasar untuk menyusun rencana pemasaran dan ketanggapan untuk mengimplementasikan.

Menurut Slater, Stanley F dan C. Narver (1990) "Orientasi pasar merupakan filosofi (teori yang mendasari alam pikiran atau suatu kegiatan) bisnis yang dipandang efektif serta efisien untuk menciptakan perilaku yang diperlukan guna menciptakan nilai yang superior bagi pembeli yang akhirnya akan berpengaruh pada kinerja pemasaran".

\section{Inovasi Produk}

Inovasi produk berkaitan erat dengan peluncuran produk. Salah satu bentuk dari inovasi produk adalah adanya produk baru. Produk baru meliputi produk orisinil, produk yang disempurnakan, produk yang dimodifikasi dan merek baru yang dikembangkan melalui usaha riset dan pengembangan.

Ada 6 kategori produk baru, antara lain :

a. Produk yang benar-benar baru, yaitu produk baru sebagai hasil dari inovasi yang menciptakan pasar baru.

b. Lini produk baru, yaitu produk baru yang memungkinkan perusahaan untuk memasuki pasar yang sebelumnya telah ada untuk pertama kali.

c. Tambahan dari lini produk yang sudah ada, misalnya bisa memberi tambahan pada ukuran bentuknya, isi yang berbeda dan sebagainya.

d. Penyempurnaan sebagai revisi terhadap produk yang sudah ada. Hal ini dapat dilakukan dengan cara menambahkan ciri-ciri atau model baru, mengubah persyaratan/kebutuhan pemrosesan, dan mengubah unsur-unsur produk.

e. Repositioning biaya. Produk baru yang menghasilkan unjuk kerja yang sama pada tingkat biaya yang lebih rendah.

Kemudian menurut Stanton dan J. William (1994) perusahaan perlu mempertimbangkan faktor-faktor dalam menentukan penambahan produk baru, yaitu

a. Harus ada permintaan pasar yang cukup besar.

b. Produk harus sesuai dengan standar sosial dan lingkungannya.

c. Produk harus sesuai dengan struktur pemasaran perusahaan yang sedang berjalan. 
d. Gagasan produk hendaknya cocok dengan fasilitas produksi, tenaga kerja dan kemampuan manajemen yang ada.

e. Produk harus layak secara finansial, yaitu dapat memberikan laba bagi perusahaan.

f. Harus tidak ada permasalahan hukum.

g. Manajemen perusahaan harus memiliki waktu dan kemampuan mengelola produk baru tersebut.

h. Produk harus sesuai dengan citra dan tujuan perusahaan.

Untuk dapat mengembangkan produk baru tersebut dapat dilakukan dengan mempertahankan daya saing terhadap produk yang sudah ada dengan menawarkan produk yang dapat memberikan jenis kepuasan baru.

\section{Kualitas Produk}

Dengan adanya perkembangan peradaban manusia, maka peranan mutu menjadi bertambah penting. Baik dipandang dari sudut konsumen yang bebas memilih tingkat mutu yang diinginkan ataupun dari sudut produsen dimana pengendalian mutu mulai diperhatikan dan menjadi satu hal yang tidak dapat dipisahkan dalam pengendalian produksi guna mempertahankan / bahkan memperluas jangkauan pemasaran.Kualitas (mutu) dapat didefinisikan sebagai jumlah dari atribut atau sifat-sifat sebagaimana didiskripsikan didalam produk jasa yang bersangkutan (Basu dan Irawan, 2001).

Kualitas (mutu) merupakan faktor yang terdapat dalam suatu produk yang menyebabkan produk tersebut bernilai sesuai dengan maksud untuk apa produk itu diproduksi. Kualitas ditentukan oleh sekumpulan kegunaan atau fungsinya, termasuk didalamnya daya tahan, ketergantungan pada produk atau komponen lain, eklusivitas, kenyamanan, wujud luar (warna, bentuk, pembungkusan, dan sebagainya).

Berdasarkan sifatnya, mutu dapat dibagi atas mutu yang bersifat ekonomis, teknis, dan mutu yang bersifat psikologis. Mutu yang bersifat ekonomis berarti bahwa barang yang bersangkutan sesuai dengan daya beli yang dimiliki oleh para konsumen. Mutu yang bersifat teknis berarti bahwa barang yang bersangkutan itu benar-benar bermutu baik sesuai yang dikemukakan kepada para konsumen. Sedangkan mutu yang bersifat psikologis, berarti bahwa barang yang bersangkutan itu memang benar-benar dapat diterima oleh masyarakat.

Kualitas memegang peranan penting dibanding dari sudut konsumen yang bebas memilih tingkat mutu atau dari sudut produsen yang mulai memperhatikan pengendalian mutu agar memperhatikan dan memperluas jangkauan pemasaran. Kualitas diukur menurut pandangan pembeli tentang mutu dan kualitas produk tersebut. Kebanyakan produk mempunyai empat kualitas yaitu: kualitas rendah, kualitas rata-rata (sedang), kualitas baik, dan kualitas sangat baik.

Peningkatan kualitas produk dirasakan sangat perlu dengan demikian produk perusahaan semakin lama semakin tinggi kualitasnya. Jika hal itu dapat dilaksanakan oleh perusahaan, maka perusahaan tersebut akan tetapi dapat memuaskan para konsumen dan dapat menambah jumlah konsumen. Dalam perkembangan suatu perusahaan, kualitas suatu produk akan ikut menentukan pesat tidaknya perkembangan perusahaan tersebut. Apabila dalam situasi pemasaran yang semakin ketat persaingannya, peranan kualitas produk akan semakin besar dalam perkembangan perusahaan.

\section{Kinerja Bisnis}

Pemasaran merupakan salah satu kegiatan perusahaan yang memegang peranan penting dalam perusahaan untuk dapat mempertahankan dan mengembangkan diri. Pemasaran merupakan kegiatan pokok, tidak ada perusahaan yang dapat bertahan jika tidak mampu memasarkan barang dan jasa yang dihasilkannya dengan baik. 
Upaya pengukuran performansi dengan menggunakan indikator dalam pemasaran yang semestinya menuju kompleksitas aktivitas organisasi, dan kenyataannya bahwa ada peningkatan sejumlah tipe industri. Persoalan lain untuk mengukur performansi dengan menerima perhatian bahwa lintas nasional sama dengan pengukuran performansi. Pengukuran keuangan yang diperbaiki telah menerima perhatian dari sudut pandang tersebut termasuk pengukuran non finansial dalam mengukur kinerja organisasi (Ittner dan Larker, 1998).

Studi lain yang dilakukan oleh Ambler dkk (2001) yakni mengukur performansi organisasi. Ambler dkk melakukan studi di Inggris dalam tiga tahap dimana pemasaran yang disampelkan dan manajemen keuangan dari berbagai sektor ind ustri termasuk retail, barang-barang konsumen, pelayanan kustomer, barang-barang penyedia bisnis, dan perusahaan pelayanan dari bisnis ke bisnis. Pengukuran penting mereka diidentifikasi, yang mana termasuk juga pengukuran finansial (misal pendapatan penjualan, marjin kotor dan saham pasar), yang dimasukkan dalam penelitian tersebut.

\section{Keunggulan Bersaing}

Fenomena-fenomena perubahan lingkungan bisnis global yang terjadi dewasa ini menuntut organisasi untuk semakin kritis menyikapinya. Persaingan yang bersifat global dan tajam menyebabkan terjadinya penciutan laba yang diperoleh perusahaan- perusahaan yang memasuki tingkat persaingan dunia. Keadaan ini memaksa manajemen mencari berbagai strategi baru yang menjadikan perusahaan mampu bertahan dan berkembang dalam persaingan tingkat dunia. Hanya perusahaan-perusahaan yang memiliki keunggulan pada tingkat dunialah yang mampu bertahan dan berkembang, yaitu perusahaan-perusahaan yang fleksibel memenuhi kebutuhan konsumen, mampu menghasilkan produk yang bermutu, dan cost effective (Mulyadi, 1997).

Keung gulan kompetitif akan dapat dicapai bila perusahaan mampu memberikan customer value yang lebih tinggi daripada kompetitor untuk kos yang sama atau customer value yang sama untuk kos yang lebih rendah. Jadi, esensi analisis value chain adalah menentukan secara tepat di mana segmen perusahaan dalam chain mulai dari desain sampai dengan distribusi, kos dapat diturunkan atau customer value dapat ditingkatkan. Dalam tulisan ini, penulis mencoba untuk mengulas bagaimana perusahaan melakukan pengelolaan aktivitas-aktivitas strategiknya dengan analisis value chain kemudian bagaimana pandangan dalam konsep value chain tersebut dikembangkan dengan hubungan kemitraan. Dengan melakukan analisis value chain perusahaan akan dapat mengerti di mana posisi cost dapat diturunkan atau customer value dapat ditingkatkan karena pengelolaan cost yang efektif memungkinkan perusahaan untuk memiliki keunggulan kompetitif sehingga mampu bersaing di pasar global. Day dan Wensley (1988) mengemukakan bahwa keunggulan bersaing seharusnya dipandang sebagai proses dinamis ketimbang sebagai hasil akhir.

\section{Kerangka Pemikiran}

Penelitian ini mengacu pada penelitian-penelitian sebelumnya. Penelitian Garret (1996) menjelaskan bahwa keunggulan bersaing dalam perusahaan jasa mempunyai hubungan yang erat dengan penggunaan sumber daya yang ada dalam perusahaan melalui peningkatan kinerja. Model dan pemanfaatan budaya yang ada dalam perusahaan merupakan kunci utama pening katan inovasi perusahaan, sehingga mampu meningkatkan keunggulan bersaing perusahaan. Hasil penelitian menunjukkan bahwa upaya perusahaan jasa dalam meraih konsumen-konsumennya dilakukan dengan penciptaan orientasi pasar dan orientasi pelanggan-pelanggannya.

Penelitian Rod B. McNaugton, Robert E. Morgan (2005) menyajikan suatu model, dimana nilai perusahaan berpengaruh secara teoritis terhadap orientasi pasar. Model tersebut berhubungan dengan penampilan yang berorientasi pada pasar 
denganmembuatmekanisme eksplisit yang mana strategi nilai konsumen dapat mempengaruhi posisi keuangan perusahaan. Sedangkan Bharadwaj et al. (1999) meneliti keunggulan bersaing berkelanjutan pada perusahaan jasa dan variabelkeunggulan bersaing berkelanjutan memiliki dimensi harus bernilai, harus jarang dimiliki oleh pesaing, harus dapat ditiru tapi tidak sempurna, harus tidak ada secara strategi yang sama untuk mensubtitusi keahlian atas sumber daya ini. Hasil penelitian tersebut menemukan bahwa keunggulan bersaing sangat penting dalam mencapai kinerja superior pada perusahaan jasa.

Eric M. Olson, Stanley F. Slater and G. Tomas M. Hult (2005) melakukan penelitian yang menguji suatu model yang sesuai, dan mendalilkan bahwa semua performansi perusahaan dipengaruhi oleh seberapa baik karakteristik struktural organisasi pemasaran (misal formalisasi, sentralisasi, dan spesialisasi) dan penekanan perilaku strategis (yakni kustomer, kompetitor, inovasi, dan pengontrolan biaya) melengkapi strategi bisnis alternatif (yakni prospektor, analiser, biaya rendah, dan perbedaan elemen pemasaran). Hasil penelitian tersebut menunjukkan bahwa terdapat hubungan yang signifikan antara strategi inovasi produk dan kesuksesan produk baru dalam memasuki pasar dengan kinerja perusahaan. Lima strategi inovasi produk yang diterapkan oleh perusahaan mampu meningkatkan kinerja perusahaan.

Berdasarkan landasan teori dan penelitian sebelumnya, dapat dibuat kerangka berpikir dalam penelitian ini sebagai berikut:

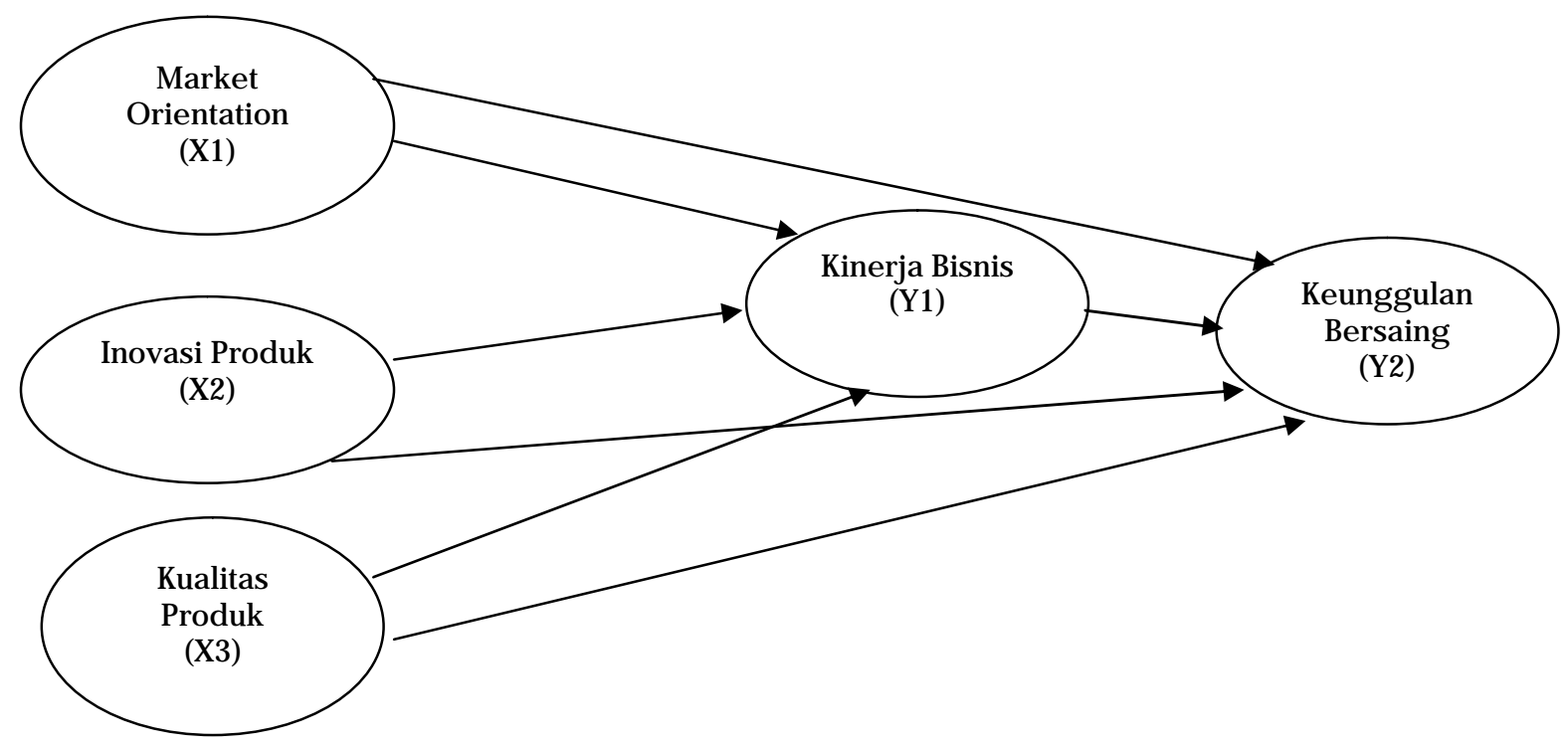

Gambar 1

Kerangka Penelitian

Kotler (1995), Eric M. Olson, Stanley F. Slater and G. Tomas M. Hult (2005), Bharadwaj et al. (1999), Rod B. McNaugton, Tony Garret (1996) 


\section{Pengaruh Market Orientation terhadap Keunggulan bersaing secara langsung maupun tidak langsung}

Pemasaran adalah suatu proses sosial dan manajerial dimana individu-individu dan kelompok-kelompok mendapatkan apa yang mereka butuhkan dan inginkan melalui penciptaan, penawaran dan pertukaran produk-produk yang bernilai. Sementra itu William J. Stanton (2003) menyatakan bahwa pemasaran adalah sistem dari keseluruhan kegiatan usaha yang ditujukan untuk merencanakan, menentukan harga, mempromosikan dan mendistribusikan barang dan jasa yang dapat memuaskan kebutuhan pembeli yang ada.

Perumusan dalam hipotesis ini mengacu pada penelitian sebelumnya. Penelitian sebelumnya yang dilakukan oleh Slater, Stanley dan Narver (1990) menjelaskan tentang dampak dari performa perusahaan dengan pendekatan strategi bisnis, struktur organisasi pemasaran dan perilaku strategis. Subin (2004) menjelaskan tentang orientasi pasar, kreatifitas produk terhadap kinerja produk baru pada perusahaan yang berteknologi tinggi. Simone A. French (2001) meneliti tentang pengaruh penetapan harga, dan promosi pada pembelian makanan dan minuman ringan rendah kalori dengan studi di Amerika.

Teori-teori pendukung dalam penelitian ini adalah sebagai berikut: Teori pemasaran dan orientasi pasar oleh Kotler (2001), dan William J Stanton (1990), untuk Keunggulan Bersaing oleh Day dan Wensley (1994), Porter (1985). Definisi orientasi pasar oleh Rod B. McNaughton (2005) dan Steward Adam (2005), sementara kinerja pemasaran oleh Eric M. Olson, Stanley dan G. Thomas M. Hult (2005).

Penelitian yang dilakukan oleh Rod B. McNaugton, Robert E. Morgan (2005) membahas tentang Market Orientation and Firm Value: A model and Analysis of the organitation of Marketing within British Telecommunications' Major Business division menyajikan suatu model, dimana nilai perusahaan berpengaruh secara teoritis terhadap orientasi pasar. Model tersebut berhubungan dengan penampilan yang berorientasi pada pasar denganmembuatmekanisme eksplisit yang mana strategi nilai konsumen dapat mempengaruhi posisi keuangan perusahaan. Hal ini menunjukkan suatu gab dalam arus penelitian yang mencari dan mendemonstrasikan hubungan empiris yang positif antara orientasi pasar dengan pengukuran pada tampilan keuangannya.

Hipotesis 1 : Market orientation berpengaruh positif dan signifikan secara langsung terhadap keunggulan bersaing.

Hipotesis 2 : Market orientation berpengaruh positif dan signifikan secara tidak langsung terhadap keunggulan bersaing melalui kinerja bisnis.

\section{Pengaruh Inovasi Produk terhadap Keunggulan Bersaing secara langsung maupun tidak langsung}

Orientasi pasar dapat digambarkan sebagai suatu budaya organisasional yang difokuskan pada pemahaman pasar yang mana membantu perusahaan tersebut untuk mengembangkan strategi nilai kustomer dengan mengambil keuntungan dari peluang yang ada dan menolak ancaman yang datang. (Rod B. McNaughton, 2005). Begitu pula bahwa hubungan orientasi pemasaran secara positif dan signifikan sangat berhubungan dengan kinerja pemasaran dan kinerja keuangan.

Sumber keunggulan kompetitif suatu perusahaan adalah aset atau sumber daya yang dapat menyediakan efisiensi dan pengurangan biaya serta perolehan pasar. Halhal yang termasuk di dalamnya adalah biaya relatif dan pengendalian bahan baku, tenaga kerja ahli, lini produk yang terdiferensiasi dengan baik, pengendalian distribusi, konsumen yang layak, reputasi perusahaan, serta teknologi yang lebih rnaju.

Eric M. Olson, Stanley, and G. Tomas M.Hult, (2005), menjelaskan kinerja pemasaran berkaitan dengan bagaimana aktivitas pemasaran diselesaikan, dan 
seberapa baik aktivitas ini diselesaikan dipengaruhi oleh bagaimana mereka diorganisir dan perilaku spesifik organisasi dalam melakukan kegaiatan berkenaan dengan orientasi kustomer, analisis kompetitor, inovasi, dan manajemen biaya.

Hasil penelitian tersebut menunjukkan bahwa terdapat hubungan yang signifikan antara strategi inovasi produk dan kesuksesan produk baru dalam memasuki pasar dengan kinerja perusahaan. Lima strategi inovasi produk yang diterapkan oleh perusahaan mampu meningkatkan kinerja perusahaan.

Hipotesis 3 : Inovasi produk berpengaruh positif dan signifikan secara langsung terhadap keunggulan bersaing.

Hipotesis 4 : Inovasi produk berpengaruh positif dan signifikan terhadap keunggulan bersaing secara tidak langsung melalui kinerja bisnis.

\section{Pengaruh Kualitas Produk terhadap Keunggulan Bersaing secara langsung maupun tidak langsung}

Orientasi pasar memberikan pengaruh terhadap kinerja perusahaan pada masing-masing level unit yang berbeda. Penelitian tersebut juga menjelaskan bahwa pada level organisasi budaya pemimpin akan mempengaruhi perilaku orientasi pasar, sehingga dapat meningkatkan kepuasan kerja karyawan dan kualitas produk yang berdampak pada peningkatan kinerja perusahaan.

Terdapat hasil penelitian yang menunjukkan bahwa dimensi-dimensi dari kualitas produk yang ada berpengaruh terhadap kinerja perusahaan. Dengan demikian sebaiknya Perusahaan dapat meningkatkan berbagai dimensi dari produk yang dimiliki sehingga memiliki kwalitas produk yang diharapkan. Begitu pula tentang upaya yang dilakukan oleh berbagai perusahaan dalam membangun strategi marketing mix untuk menciptakan keunggulan bersaing perusahaan. Upaya dalam membangun strategi marketing mix yang dilakukan oleh perusahaan dimulai dari kinerja para menejernya.

$\begin{array}{ll}\text { Hipotesis 5: } & \begin{array}{l}\text { Kualitas produk berpengaruh positif dan signifikan terhadap } \\ \text { keunggulan bersaing secara langsung. }\end{array} \\ \text { Hipotesis } 6: & \begin{array}{l}\text { Kualitas produk berpengaruh positif dan signifikan secara tidak } \\ \text { langsung terhadap keunggulan bersaing melalui kinerja bisnis. }\end{array} \\ \text { Hipotesis } 7: \begin{array}{l}\text { Kinerja bisnis berpengaruh positif dan signifikan secaralangsung } \\ \text { terhadap keunggulan bersaing. }\end{array}\end{array}$

\section{METODE PENELITIAN}

\section{Jenis Penelitian}

Jenis penelitian yang dipergunakan dalam penelitian ini adalah penelitian asosiatif yang menggambarkan korelasional antara dua variabel atau lebih. Dalam penelitian ini penelitian yang bersifat asosiasitif yang menguji tentang causal variabel bebas yang mempengaruhi variabel terikat.

\section{Populasi, Sampel dan Sampling}

1. Populasi

Adapun yang menjadi populasi dalam penelitian ini adalah semua outlet dan kelompok tani yang menggunakan produk CV Multi Global Agrindo di Pulau Jawa sebanyak 260. Menurut Ferdinand (2006) dalam metode analisis data dengan menggunakan Structural Equation Modelling (SEM) jumlah responden yang diteliti minimal adalah 100 responden. Sedangkan jumlah populasi yang ada pada CV Multi Gobal Agrindo adalah sebanyak 260 responden. Jadi jumlah populasi sudah memenuhi. 
2. Sampel

Sampel yang akan diambil untuk diteliti adalah 150 manager outlet CV Multi Global Agrindodan kelompok tani yang ada di Pulau Jawa. Pengambilan sampel menurut Hair (1988) apabila dengan menggunakan SEM dengan 5 - 10 kali jumlah indikator. Dalam penelitian ini peneliti mengambil acuan sampel 5 kali jumlah indikator yaitu 5 kali 30 sehing ga sampel sebanyak 150 responden.

3. Sampling

Sampling dalam penelitian ini dengan menggunakan convinience sampling, yaitu pengambilan sampel dengan cara peneliti memiliki kebebasan untuk memilih siapa saja yang mereka temui.

\section{Sumber Data dan Metode Pengumpulan Data}

1. Data

Data primer dalam penelitian ini berupa kuisioner yang disebarkan kepada outlet dan kelompok tani yang memasarkan produk CV. Multi Global Agrindo (MGA) yang berupa persepsi tentang market orientation, inovasi produk, dan kualitas produk terhadap kinerja bisnis dalam menciptakan keunggulan bersaing pada CV. Multi G lobal Agrindo.Data sekunder dalam penelitian ini berupa profile dan produk yang dijual oleh CV. Multi Global Agrindo (MGA).

2. Metode Pengumpulan Data

a. Wawancara

Disini tanya jawab dilakukan langsung dengan pihak yang berkompeten, yang mengetahui tentang produk dari CV. MGA. Metode pengumpulan data wawancara merupakan data primer yang didapatkan dari hasil wawancara dengan outlet yang menjual produk dari CV. MGA.

b. Angket (hasil penyebaran kuesioner)

Kuesioner yaitu teknik pengumpulan data yang dilakukan dengan cara memberi seperangkat pertanyaan tertulis kepada responden untuk dijawab, dan kemudian diolah. Dalam memberikan pilihan jawaban atas pertanyaan dari variabel-variabel tersebut, menggunakan "Skala Likert". Skala memilih alternatif antara 1 sampai 5 dengan pemberian skor sebagai berikut:

$$
\begin{aligned}
& 5 \text { = Sangat Setuju (SS) } . \\
& 4=\text { Setuju (S). } \\
& 3=\text { Ragu-ragu (R). } \\
& 2=\text { Tidak Setuju (TS). } \\
& 1=\text { Sangat Tidak Setuju (STS) } .
\end{aligned}
$$

\section{Definisi Operasional Variabel Penelitian}

Definisi operasional adalah suatu definisi yang diberikan kepada suatu variabel atau konstruk dengan cara memberikan arti dengan tujuan mengukur variabel atau konstruk (Nazir, 1999). Menurut Azwar (1997) konstruk atau konsepsi teoritik didefinisikan secara operasional dalam bentuk indikator-indikator agar dapat diukur. Data kuisioner yang diolah dianggap sebagai data interval walaupun datanya bertingkat. Dalam pengumpulan data, data dilihat dulu distribusinya, kalau distribusinya tidak normal maka diolah dengan menggunakan metode statistik non parametrik. Definisi operasional dari variabel penelitian ini dapat dijelaskan sebagai berikut:

a. Market Orientation

Orientasi pasar adalah tindakan nyata yang memungkinkan perusahaan mempertahankan variasi permintaan dan penawaran dan memberikan respon yang tepat terhadap berbagai perubahan yang terjadi. Orientasi pasar diukur melalui indikator :

1) Orientasi pada pelanggan. 
2) Informasi pesaing

3) Koordinasi lintas fungsi.

b. Inovasi Produk

Inovasi produk merupakan kegiatan yang dilakukan oleh perusahaan dengan menggunakan metode dan alat, serta peningkatan kemampuan tenaga kerja untuk mengurangi barang-barang dalam keadaan cacat agar mampu meningkatkan kualitas. Inovasi produk dalam penelitian ini diukur dengan indikator:

1) Inovasi melalui metode

2) Inovasi melalui penggunaan alat

3) Inovasi melalui pelatihan tenaga kerja.

c. Kualitas Produk

Kualitas produk merupakan kekuatan produk di benak konsumen dan dapat bersaing di pasar. Kualitas produk dalam penelitian ini diukur dengan indikator sebagai berikut:

1) Kesesuain dengan selera konsumen.

2) Diterima oleh pasar

3) Desain kualitas

d. Kinerja Bisnis

Kinerja bisnis merupakan prestasi yang dicapai oleh perusahaan yang dilihat dari hasil kerja pemasarannya. Kinerja bisnis diukur melalui indikator :

1) Volume penjualan.

2) Pertumbuhan pelanggan.

3) Pertumbuhan penjualan.

e. Keunggulan Bersaing

Keunggulan bersaingmerupakan upaya yang dilakukan perusahaan dengan kemampuannya untuk dapat menghasilkan tingkat penjualan dan laba yang lebih tinggi dibandingkan dengan pesaingnya. Dalam penelitian ini keunggulan bersaing diukur dengan instrumen indikator meliputi :

1) Nilai-nilai langka dari perusahaan.

2) Durabilitas perusahaan.

3) Imitabilitas perusahaan

\section{HASI L ANALISISDAN PEMBAHASAN}

Tabel dibawah ini menunjukkan secara rinci hubungan pengaruh langsung, pengaruh tidak langsung, dan pengaruh total pada penelitian ini.

Tabel 1. Pengaruh Langsung, Tidak Langsung dan Pengaruh Total

\begin{tabular}{|cccc|}
\hline Pengaruh & $\begin{array}{c}\text { Direct } \\
\text { Effects }\end{array}$ & $\begin{array}{c}\text { Indirect } \\
\text { Effects }\end{array}$ & $\begin{array}{c}\text { Total } \\
\text { Effects }\end{array}$ \\
\hline Orientasi pasar $\rightarrow$ Keunggulan Bersaing &, 425 &, 032 &, 457 \\
Kualitas Produk $\rightarrow$ Kinerja Bisnis &, 355 &, 000 &, 355 \\
Inovasi $\rightarrow$ Keunggulan Bersaing &, 245 &, 322 &, 567 \\
Inovasi $\rightarrow$ Kinerja Bisnis &, 122 &, 000 &, 122 \\
Orientasi pasar $\rightarrow$ Kinerja Bisnis &,- 216 &, 000 &,- 216 \\
Kualitas Produk $\rightarrow$ Keunggulan Bersaing &, 725 &, 112 &, 837 \\
Keunggulan Bersaing $\rightarrow$ Kinerja Bisnis &, 648 &, 000 &, 648 \\
\hline
\end{tabular}

Sumber: Data diolah 2014

Berdasarkan Tabel 1 dan gambar 2dapat dijelaskan bahwa pengaruh langsung dari orientasi pasar terhadap keunggulan bersaing adalah positif dan signifikan, 
sedangkan secara tidak langsung positif tapi tidak signifikan. Pengaruh langsung inovási produk terhadap keunggulan bersaing secara langsung adalah positif dan signifikan, sedangkan secara tidak langsung positif dan signifikan. Pengaruh langsung kualitas produk terhadap keunggulan bersaing secara langsung adalah positif dan signifikan, sedangkan secara tidak langsung positif dan signifikan. Pengaruh langsung kinerja bisnis terhadap keunggulan bersaing adalah positif dan signifikan. Hasil penelitian juga menunjukkan bahwa innováis produk merupakan variable yang paling efektif berpengaruh secara langsung terhadap keunggulan bersaing yang ditunjukkan nilai signifikansi sebesar 0,000 .

Berdasarkan tabel tersebut dapat dijelaskan pada gambar dibawah.

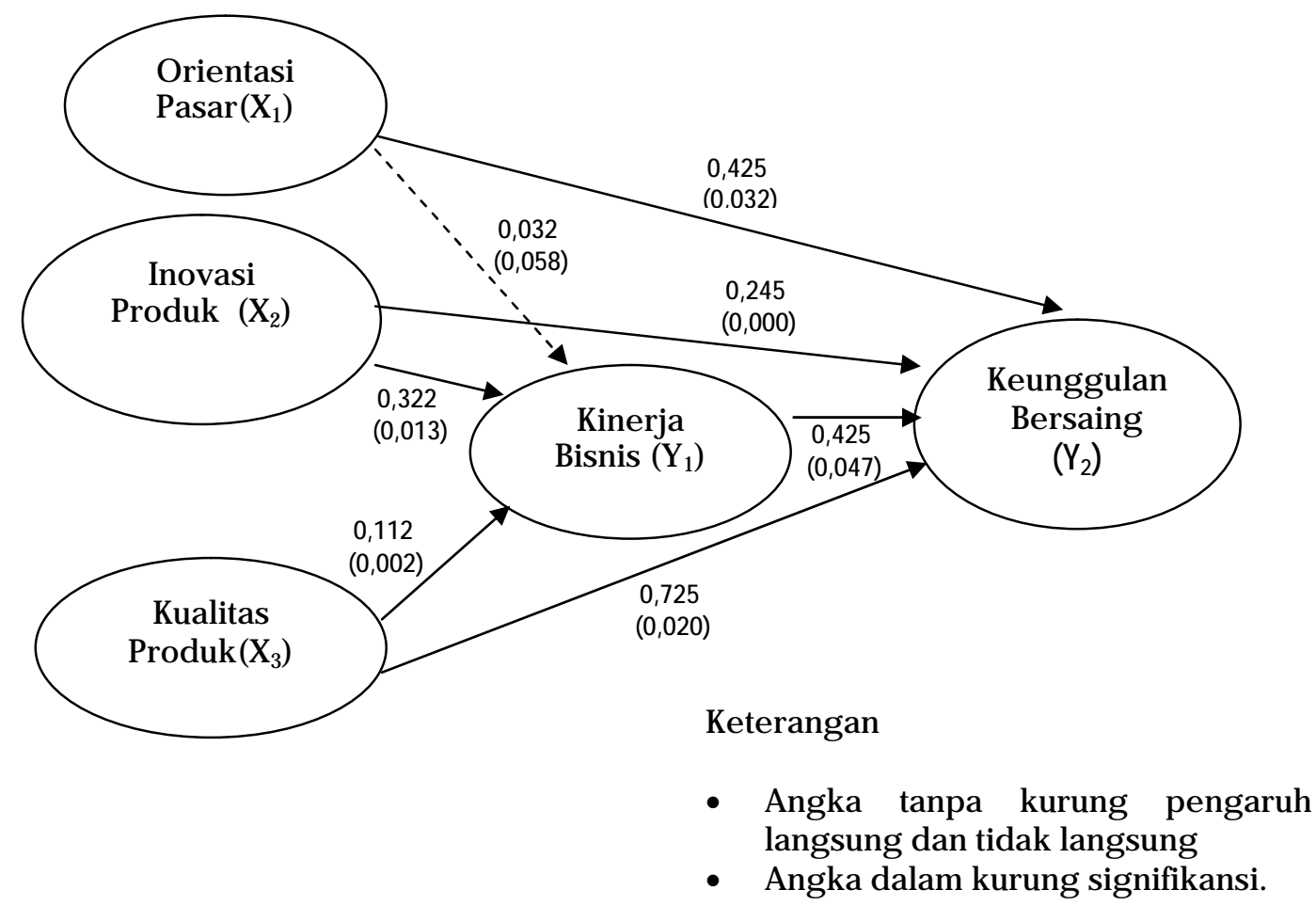

\section{Gambar 2. Hasil Uji Hipotesis}

\section{Hasil Pengujian Hipotesis 1}

Orientasi pasar berpengaruh positif dan signifikan secara langsung terhadap keunggulan bersaing. Gambar 4.8, menunjukkan bahwa terdapat pengaruh langsung yang positif signifikan dari orientasi pasar terhadap keunggulan bersaing sebesar 0,425 dan dengan nilai probabilitas sebesar 0,032 (probabilitas $<0,05$ ). Artinya terdapat pengaruh yang searah orientasi pasar yang ada pada produk yang di peroleh dari CV. MGA, dengan keunggulan bersaing. Hal ini berarti hipotesis 1 diterima.

\section{Hasil Pengujian Hipotesis 2}

Orientasi pasar berpengaruh positif dan signifikan secara tidak langsung terhadap keunggulan bersaing melalui kinerja bisnis. Hasil penelitian menunjukkan bahwa terdapat pengaruh tidak langsung yang Positif tapi tidak signifikan dari orientasi pasar terhadap kinerja bisnis sebesar 0,032 dan dengan nilai probabilitas sebesar 0,058 (probabilitas $>0,05$ ). Artinya terdapat pengaruh yang berbanding arah 
antara orientasi pasar yang ada pada produk yang di peroleh dari CV. MGA, dengan keung gulan bersaing melalui kinerja bisnis. Hal ini berarti hipotesis 2 ditolak.

\section{Hasil Pengujian Hipotesis 3}

Inovasiproduk berpengaruh positif dan signifikan secara langsung terhadap keunggulan bersaing. Hasil penelitian menunjukkan bahwa terdapat pengaruh langsung yang Positif dan signifikan dari Inovasiproduk terhadap keunggulan bersaing sebesar 0,245 dan dengan nilai probabilitas sebesar 0,013 (probabilitas < $0,05)$. Artinya terdapat pengaruh yang searah antara Inovasiproduk yang ada pada produk yang di peroleh dari CV. MGA, dengan keunggulan bersaing. Hal ini berarti hipotesis 3 diterima.

\section{Hasil Pengujian Hipotesis 4}

Inovasiproduk berpengaruh tidak langsung Positifdan signifikan terhadap keunggulan bersaing melalui kinerja bisnis. Hasil penelitian menunjukkan terdapat pengaruh tidak langsung yang Positif dan signifikan dari Inovasiproduk terhadap keunggulan bersaing sebesar 0,322 dan dengan nilai probabilitas sebesar 0,013 (probabilitas $<0,05$ ). Artinya terdapat pengaruh yang searah antara Inovasiproduk yang ada pada produk yang di peroleh dari CV. MGA, dengan keunggulan bersaing melalui kinerja bisnis. Hal ini berarti hipotesis 4 diterima.

\section{Hasil Pengujian Hi potesis 5}

Kualitas produk berpengaruh secara langsung terhadap keunggulan bersaing. Hasil penelitian menunjukkan bahwa terdapat pengaruh langsung yang positif dan signifikan dari kualitas produk terhadap keunggulan bersaing sebesar 0,725 dan dengan nilai probabilitas sebesar 0,020 (probabilitas $<0,05$ ). Artinya terdapat pengaruh yang searah antara kualitas produk yang ada pada produk yang di peroleh dari CV. MGA, dengan keunggulan bersaing. Hal ini berarti hipotesis 5 diterima.

\section{Hasil Pengujian Hipotesis 6}

Kualitas produk berpengaruh secara tidak langsung terhadap keunggulan bersaing melalui kinerja bisnis. Hasil penelitian menunjukkan bahwa terdapat pengaruh tidak langsung yang Positif dan signifikan dari kualitas produk terhadap keunggulan bersaing melalui kinerja bisnis sebesar 0,112 dan dengan nilai probabilitas sebesar 0,002 (probabilitas <0,05). Hal ini berarti hipotesis 6 diterima.

\section{Hasil Pengujian Hipotesis 7}

Kinerja bisnis berpengaruh secara langsung terhadap keunggulan bersaing. Hasil penelitian menunjukkan bahwa terdapat pengaruh langsung yang Positif dan signifikan dari kinerja bisnis terhadap keunggulan bersaing sebesar 0,425 dan dengan nilai probabilitas sebesar 0,047 (probabilitas < 0,05). Hal ini berarti hipotesis 7 diterima.

\section{Pembahasan}

\section{Pengaruh orientasi pasar terhadap keunggulan bersaing}

Berdasarkan hasil analisis data dinyatakan bahwa orientasi pasar berpengaruh Positif dan signifikan terhadap keunggulan bersaing secara langsung. Selain terbukti secara empiris melalui uji lapangan, jadi hipotesis dapat dibuktikan melalui kajian literatur, Vorhies, Harker, dan Rao, (1999), Rod B. McNaughton (2005) , Narver dan Slater, (1990). Berdasarkan kaidah ini maka dapat ditarik analisis bahwa dengan melaksanakan orientsi pasar maka akan, meningkatkan kinerja pemasaran.

Sedangkan konsep orientasi pasar menurut Richard A. Heiens, University of South Carolina Aiken, Academy of Maketing Science Review, (2000) adalah suatu 
aspek pada budaya organisasi yang diyakini mempunyai efek-efek yang luas terhadap perusahaan. Menurut Deshpande dan Webster (1989), aspek yang paling relevan pada budaya organisasi dari perspektif pemasaran adalah konsep pemasaran, yang meliputi sekelompok keyakinan dan nilai-nilai fundamental yang dipakai bersama, yang menempatkan konsumen di pusat pemikiran perusahaan dalam hal keunggulan dan operasi-operasi.

Hasil penelitian juga menunjukkan bahwa terdapat pengaruh tidak langsung yang Positif dan tidak signifikan dari orientasi pasar terhadap kinerja bisnis. Hasil penelitian ini berbanding terbalik hasil penelitian Rod B. McNaughton (2005) yang menjelakan Orientasi pasar dapat digambarkan sebagai suatu budaya organisasional yang difokuskan pada pemahaman pasar yang mana membantu perusahaan tersebut untuk mengembangkan keunggulan nilai kustomer dengan mengambil keuntungan dari peluang yang ada dan menolak ancaman yang datang. Disisi lain Kohli dan Jaworski (1990) menggambarkan orientasi pasar sebagai kemampuan suatu organisasi untuk menghasilkan, menyebarkan, dan menggunakan informasi-informasi yang terbaik mengenai konsumen dan pesaing.

\section{Pengaruh Inovasi Produkterhadap keunggulan bersaing}

Berdasarkan hasil analisis data yang ditunjukkan dinyatakan bahwa inovasi berpengaruh Positif signifikan, terhadap kinerja pemasaran secara langsung. Hal ini menerima hipotesis yang ada. Hasil penelitian ini mendukung dengan penelitian yang dilakukan oleh Eric M. Olson, Stanley F. Slater \& G. Tomas M. Hult (2005) dengan hasil penelitiannya menguji suatu model yang sesuai, dan mendalilkan bahwa semua performansi perusahaan dipengaruhi oleh seberapa baik karakteristik struktural organisasi pemasaran (misal formalisasi, sentralisasi, dan spesialisasi) dan penekanan perilaku Keunggulan (yakni kustomer, kompetitor, inovasi, dan pengontrolan biaya) melengkapi keunggulan bisnis alternatif (yakni prospektor, analiser, biaya rendah, dan dan perbedaan elemen pemasaran).

Hasil penelitian ini mendukung penelitian yang dilakukan oleh Larry Dawyer and Robert Mellor (1993) menjelaskan tentang strategi inovasi produk dan kinerja perusahaan-perusahaan di Australia. Hasil penelitian tersebut menunjukkan bahwa terdapat hubungan yang signifikan antara strategi inovasi produk dan kesuksesan produk baru dalam memasuki pasar dengan kinerja perusahaan. Lima strategi inovasi produk yang diterapkan oleh perusahaan mampu meningkatkan kinerja perusahaan.

Hasil penelitian ini juga mendukung penelitian yang dilakukan oleh Subin Im and John P. Workman Jr., (2004) dengan judul : Market Orientation, Creatifity, and New Product Performance in Hight - Technology Firms", dengan tujuan penelitian sebagai berikut: 1) apakah orientasi pasar memudahkan atau menghambat kreativitas organisasi, (2) apakah kreativitas mempengaruhi performansi New Product bagi organisasi, dan (3) bagaimana mendefinisikan dan mengukur kreativitas dalam pengembangan New Product dan konteksnya dengan peluncuran produk. Mereka menggunakan kerangka pengambilan sampel dua tahap untuk mengumpulkan 312 respon dari para manajer dan para pemimpin tim New Product dan dengan cara demikian mengalamatkan potensial bagi bias metode umum dalam pengukuran kreativitas dan performansi New Product dalam organisasi.

Hasil temuan dalam penelitian tersebut mengindikasikan bahwa kreativitas New Product dan marketing program menunjukkan hubungan antara orientasi pasar dan keberhasilan New Product. Penulis juga menunjukkan bahwa dimensi itu berarti, daripada dimensi yang baru, kreativitas merupakan kepentingan yang lebih besar dalam menerangkan hubungan antara orientasi pasar dan keberhasilan. Hasil empiris menyediakan implikasi teoritis yang signifikan dan manajerial bagi strategi New Product. 


\section{Pengaruh kualitas produk dengan keunggulan bersaing}

Berdasarkan hasil analisis data bahwa kualitas produk berpengaruh positif dan signifikan terhadap keunggulan bersaing. Hal ini sesuai dengan teori yang ada dan secara empiris melalui uji lapangan tidak terbukti dengan pendapat Kotler (2005), dan William J Stanton (2003) yang menjelaskan kaidah bahwa semakin tinggi kualitas produk maka akan semakin meningkatkan nilai keunggulan bersaing.

Sementara itu Stanton (2003), menjelaskan bahwa kualitas produk adalah suatu sifat yang komplek baik yang dapat diraba maupun tidak termasuk bungkus, warna, harga, prestise perusahaan dan pengecer, pelayanan perusahaan dan pengecer yang dapat diterima oleh pembeli untuk memuaskan keinginan atau kebutuhan. Jadi keputusan tentang produk mencakup penentuan bentuk fisik, merek, pembungkus garansi dan service sesudah penjualan, semua unsur tersebut dipandang sebagai alat pemuas kebutuhan pembeli.

Hasil penelitian ini searah dengan teori pemasaran dan bauran pemasaran oleh Kotler (2005), dan William J Stanton (2003), yang menyatakan bahwa pemasaran adalah sistem dari keseluruhan kegiatan usaha yang ditujukan untuk merencanakan, menentukan harga, mempromosikan dan mendistribusikan barang dan jasa yang dapat memuaskan kebutuhan pembeli yang ada. Sementara Bauran pemasaran merupakan kumpulan dari variabel pemasaran tertentu dari setiap unsur P (Product, Price, Promotion, Place) dan sebagai inti dari sistem pemasaran. Penelitian ini juga searah dengan hasil penelitian Majit (2007), dan Herry Cahyono (2007), yang menyatakan bahwa; Faktor produk dari bauran pemasaran signifikan mempengaruhi keputusan pembelian, yang berakibat naiknya kinerja pemasaran.

\section{Pengaruh kinerja bisnis dengan keunggulan bersaing}

Berdasarkan hasil analisis data dinyatakan bahwa kinerja bisnis berpengaruh Positif dan signifikan terhadap keunggulan bersaing. Hasil ini menunjukkan besar pengaruh kinerja bisnis terhadap keunggulan bersaing perusahaan dari CV. MGA. Hasil penelitian ini searah dan mendukung penelitian, Francis Blanch \& Christele (2006), Tonny Garret (1996), yang menyimpulkan bahwa keunggulan bersaing perusahaan berhasil meningkatkan kinerja perusahaan. Sementara Bharadwaj et al. (1993), menyatakan bahwa keunggulan bersaing sangat penting dalam mencapai kinerja superior pada perusahaan, dimana keunggulan bersaing dapat diperoleh dengan memiliki seperangkat keahlian dan kompetensi yang unik sehingga sulit ditiru oleh para pesaing.

\section{SIMPULAN}

1. Orientasi pasar berpengaruh positif secara langsung terhadap keunggulan bersaing.Artinya terdapat pengaruh yang searah orientasi pasar yang ada pada produk yang di peroleh dari CV. MGA, dengan keunggulan bersaing.

2. Orientasi pasar tidak berpengaruh secara tidak langsung terhadap keunggulan bersaing melalui kinerja bisnis.Artinya terdapat pengaruh yang berbanding arah antara orientasi pasar yang ada pada produk yang di peroleh dari CV. MGA, dengan keung gulan bersaing melalui kinerja bisnis.

3. Inovasiproduk berpengaruh positif secara langsung terhadap keunggulan bersaing. Artinya terdapat pengaruh yang searah antara Inovasiproduk yang ada pada produk yang di peroleh dari CV. MGA, dengan keunggulan bersaing.

4. Inovasiproduk berpengaruh tidak langsung Positif terhadap keunggulan bersaing melalui kinerja bisnis.Artinya terdapat pengaruh yang searah antara Inovasiproduk yang ada pada produk yang di peroleh dari CV. MGA, dengan keunggulan bersaing melalui kinerja bisnis. 
5. Kualitas produk berpengaruh positif secara langsung terhadap keunggulan bersaing. Artinya terdapat pengaruh yang searah antara kualitas produk yang ada pada produk yang di peroleh dari CV. MGA, dengan keunggulan bersaing.

6. Kualitas produk berpengaruh positif secara tidak langsung terhadap keunggulan bersaing melalui kinerja bisnis.Artinya terdapat pengaruh yang searah antara kualitas produk yang ada pada produk yang di peroleh dari CV. MGA, dengan keunggulan bersaing melalui kinerja bisnis.

7. Kinerja bisnis berpengaruh secara langsung terhadap keunggulan bersaing. Artinya terdapat pengaruh yang searah antara kinerja bisnis yang ada dengan keunggulan bersaing CV. MGA.

\section{Saran}

1. Mengingat besarnya peran pemasaran khususnya orientasi pasar, dan kualitas produk terhadap kinerja pemasaran, maka disarankan agar CV. MGA, selalu melakukan inovasi-inovasi produk baik dari sisi model perbenihan, maupun model hasil produksi yang disesuaikan dengan trend mode, dengan harga yang pantas dan layak, sehingga para petani mendapatkan produk yang baik dengan harga yang sesuai.

2. Keunggulan bersaing memegang peranan penting dalam meningkatkan kinerja bisnis, maka pihak perusahaan hendaknya lebih serius dalam melaksanakan peran keunggulan bersaing, dimana keunggulan bersaing merupakan sarana (perusahaan) yang digunakan untuk mencapai tujuannya, dan mengimplikasikan konsep manajemen, sehingga selalu unggul dari pesaingnya.

3. Penelitian mendatang dapat diarahkan untuk menjelaskan secara detail celah-celah yang terdapat pada penelitian ini. Aspek-aspek yang dapat diteliti lebih lanjut yang berhubungan dengan bauran pemasaran khususnya pada variabel distribusi yang pada penelitian ini didapat pengaruh yang negatip, dan juga pada variable orientasi pasar, dan keunggulan bersaing bila di tinjau dari bisnis lainnya.

4. Melihat perkembangan pasar yang diinformasikan dari hasil deskripsi statistik, data orientasi pasar masih perlu ditingkatkan melalui riset pasar untuk menentukan posisi perusahaan, segmen pasar, target pasar, sehingga perusahaan bisa menciptakan peluang mendapatkan keungulan dalam bersaing.

\section{DAFTAR PUSTAKA}

Ambler, et al. 2001. Gaining and Sustaining Competitive Advantage, $2^{\text {nd }}$ edition, Upper Saddle River, New York: Prentice-Hall.

Basu Swatha, dan Irawan. 1990. Manajemen Pemasaran Modern. Yogyakarta: Liberty.

Bharadwaj, S.G, Varadarajan, P.R, and Pahy, Jayachandran, 1999, Sustainable Competitive Advantage In Service Ind, urtries: A Conceptual Model and Research Propositions, Journal of Marketing, Vol. 57 (O ctober), pp. 83-100.

Day, George S. and R. Wensley, 1988, Marketing Theory With a Strategic Orientation, Journal of Marketing, Vol. 47, No.4, pp. 68-79

Eric M. OIson, Stanley, and G. Tomas M.Hult, 2005, The Performance Implications Of Fit Among Business Strategy, Marketing Organization Structure, and Strategic Behavior. Journal Of Marketing, Performance Implication of Fit, vol 69 (Juli 2005), $49-65$.

Ferdinand, Agusty; Tae, 1991. An analysis Marketing Instrument in the competitive market, an applied study of the Japanese automobile industry, The Hikone Ronso, Journal of economic society, Shiga University, Japan.

Hair, J. F., Anderson, R.E., Tatham, R.L. and Black W. C., 1988, Multivariat Date Analysis, $5^{\text {th }}$ Edition, Prentice Hall Inc, Upper Saddle River, New Jersey. 
Kohli Ajay K., and Bernard J. Jaworski, 1993, Market Orientation: The Construct, Research proposition, and Managerial Implications, Journal of Marketing, Vol. 54 (April), pp. 1-18.

Mulyadi, 1997. Akuntansi Manajemen. BPFE. UGM. Yogjakarta.

Nazir, Mohammad, 1999, Metode Penelitian, Edisi Kelima, Penerbit Ghalia Indonesia, Jakarta.

Philip Kotler. 1995. Manajemen Pemasaran: Analisis, Perencanaan, Implementasi dan Pengendalian. Jakarta: Salemba Empat.

Porter, Michael E., 1985, Competitive Strategy, The Free Press, New York

Rod B. McNaughton. Universitas of Otaga, Robert E. Morgan. Universitas of Wales Aberrystwyth Gopal Kutwaroo. BT and University of Wales Aberrystwyth) New zeeland. 2005, Market Oriontation and Firm Value:Journal of marketing.

Slater, Stanley F., and John C. Narver, 1990, Marked Orientation and The learning Organization, Journal of Marketing, 59 (July), pp. 63-74.

Simone A. French, Phd. Mary Story, Kyle K. Briethlow, BS, Judith, Phd. Peter Hannan, MSat. And M. Patricia Snyder, RD, MA. Pricing and Promotion Effects on Low- Fat Vending Snack Purchases: The CHIPS Study. American Journal of Public Health. January 2001. Vol 91. September.

Subin Im \& John P. Workman Jr. 2004, Market Orientation, Creativity, and New Product Performance in Higt- Technology Firms. Journal Of Marketing, 2004, hal 114 : 132.

Stanton, J. William, 1990, Prinsip-prinsip Pemasaran, Edisi 9 Erlangga, Jakarta.

Steward Adam, 2005,Relationship Management, the Web and Organisational Performance in Australia. Deakin University, Electronic Marketing, pp. $1: 9$

Tonny Garret, 1996, Service Product Development For Sustainable Competitive Advantage : The Use Of The Sources - Position And Performance Model, Journal of Strategic Marketing, 2 Jun, pp. 112-130. 
Jurnal Bisnis \& M anajemen

Vol. 17, N o. 2, 2017 : 51 -68 